жению, а документальный театр действует на художника как «холодный душ», лишая желание к самопрезентации. Документальный театр является методом, ограничивающим свободу художника и в этом своем свойстве представляет чрезвычайно полезный инструмент для образования. Помимо этого, документальный театр является междисциплинарной практикой, которая требует в какой-то степени овладения основами профессии, как журналиста, так и драматурга.

Режиссёр Юрий Квятковский в одном из интервью обозначил возможности документального театра в обучении актёров и режиссёров таким образом: «Они ещё почти дети, но оказывается, что они тоже в состоянии формулировать смыслы. Помимо этого, вербатим помогает вложить в студентов мысль, что театр это гражданский институт, что надо как-то находить себя в этом институте. Наблюдая за какими-то бытовыми, социальными вещами, можно выйти на метафизический уровень» [7].

Таким образом, можно заключить, что документальный театр способствует формированию активной позиции художника, где художник выступает не только в качестве наблюдателя за реальностью, а личностно включается в изучение повседневности. Спектакли, сделанные таким образом, становятся отражением голоса своего поколения с отчетливой гражданской позицией.

\section{Список литературы}

1. Грачёва Л. В. «Есть такая профессия театральный педагог» // Театральная педагогика глазами молодых режиссёров. Санкт-Петербург, 2019. С. 6-12.

2. Товстоногов Г. А. Зеркало сцены. Кн.1: О профессии режиссёра. Ленинград, 1980. $303 \mathrm{c}$.

3. Д. Сибрук. Nowbraw. Москва, 2012. $500 \mathrm{c}$.

4. Богданова П. Культурный цикл: театральная режиссура от шестидесятников к поколению post. Москва, 2017. 479 с.

5. Товстоногов Г. А. Беседы с коллегами: (попытка осмысления режиссерского опыта). Москва, 1988. 527 с.

6. Руднев П. А. Драма памяти. Очерки истории российской драматургии от Розова до наших дней. Москва, 2018. 496 с.

7. Нужно инвестировать в актёрское образование // URL: http://brusfestblog.ru/rudnev-actobrazovanie (25.02.2021).
Н. Н. Головченко, кандидат исторических наук Алтайский государственный педагогический университет (Барнаул, Россия) nikolai.golowchenko@yandex.ru

\title{
СЦЕНА БЛИЗНЕЧНОГО КУЛЬТА НА ПЛАСТИНКЕ ИЗ ПОС. КИСЛУХА (ПЕРВОМАЙСКИЙ РАЙОН): СУДЬБА ОДНОЙ НАХОДКИ
}

Аннотация. Статья посвящена введению в научный оборот находок (вислообушный топор, два ножа и художественно выполненная нашивная пластинка), выявленных любителем незаконного металлопоиска в поселке Кислуха Первомайского района Алтайского края. Наибольший интерес в данном собрании представляет плоскорельефная пластинка культового литья кулайской археологической культуры, на которой изображены «близнецы». Охарактеризованы одежда и прическа данных персонажей. Предлагается их интерпретация как женщин-сестер или матери с дочерью. Датируется такой образ эпохой раннего железа - раннего средневековья.

Ключевые слова: Верхнее Приобье, эпоха раннего железа, кулайская культура, близнечный культ.

Одним из актуальнейших и животрепещущих вопросов современной охраны объектов историко-культурного наследия является проблема неконтролируемого металлопоиска, приводящего к разрушению объектов археологиче- ского наследия, исчезновению для науки как целостного комплекса, так и его отдельных составляющих путем продажи частным коллекционерам. Введению в научный оборот такой, 
случайно попавшей в поле зрения автора, находки посвящена настоящая работа.

В мае 2021 года до меня дошла информация об обнаружении любителем «черного поиска» нескольких археологических вещей в пос. Кислуха Первомайского района Алтайского края. Судьба и качественный состав находок оставались неизвестными до тех пор, пока не появилось объявление о их продаже на сайте Авито.ру. Указав ряд неточных сведений о своем местонахождении и месте находки, мародер оценил предметы историко-культурного наследия народов, населявших нашу малую родину две тысячи лет назад, всего в 1 рубль. Выйти на контакт с «находчиком» удалось через упомянутый сайт где в переписке он сообщил, что вещи якобы переданы им в музей, не указав при этом в какой именно.
В археологической литературе, в целом, не принято публиковать вещи, оторванные от контекста их обнаружения, но данный случай просто выходит за все рамки дозволенного молчания, так как выявленные вещи на самом деле уникальны (рис. 1). Находки на территории нашего края вислообушных топоров и ножей эпохи раннего железа известны и случались не раз, об этом красноречиво свидетельствует их фактическое наличие в составе фондов районных и городских краеведческих музеев, но применительно к качественно выполненной кулайской металлопластики этого сказать нельзя. Уместно напомнить при этом, что именно кулайский Новообинцевский клад является украшением экспозиции Алтайского государственного краеведческого музея [1, с. 96-114].

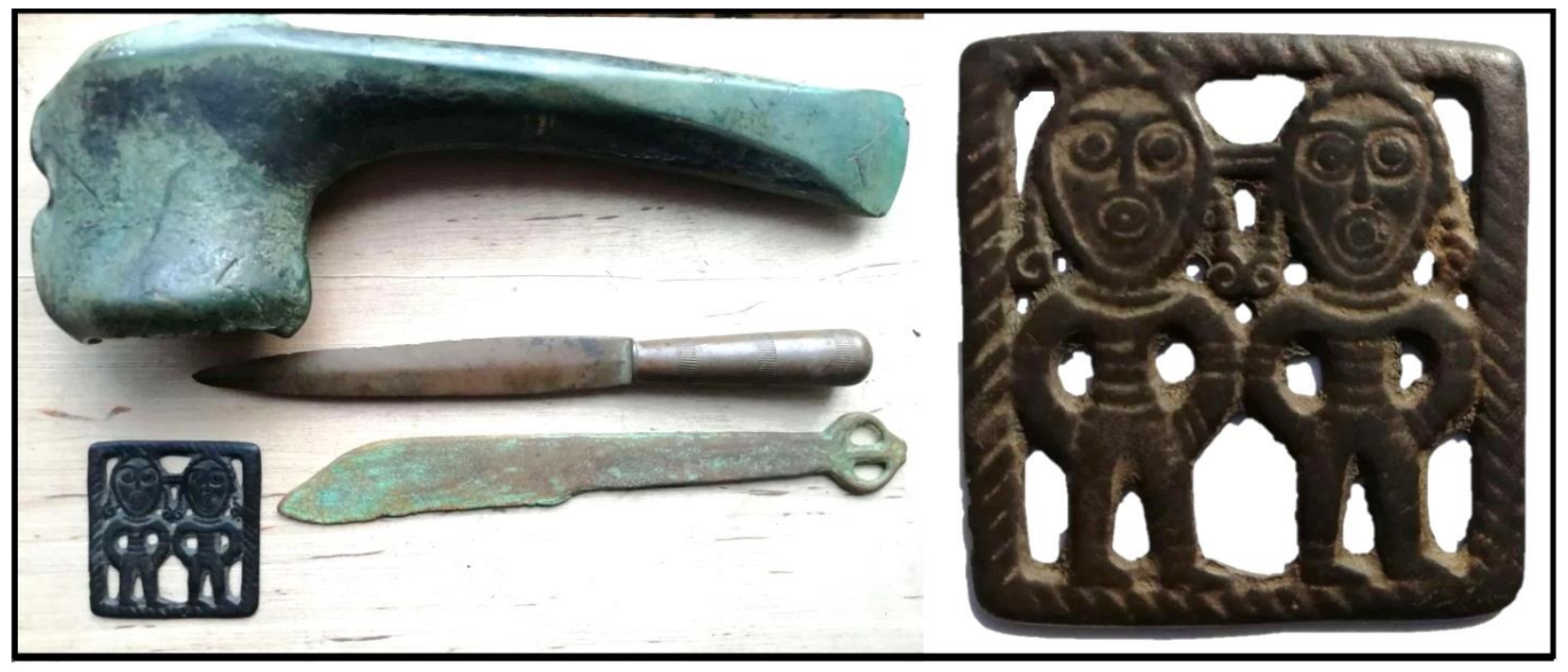

Рис. 1. Находки из пос. Кислуха

Добытая вандалом плоскорельефная литая пластинка со сценой близнечного культа относится к категории достаточно распространенных по Западной Сибири вещей (подобная находка известна из окрестностей г. Бийска). Датируется такой образ в основном эпохой раннего железа, но распространен до раннего средневековья [2, с. 54-66].

Судя по фото, представленному на сайте Авито.ру, кислухинская пластинка имеет размеры 4,5x4,5 см, ее лицевая сторона заполирована. Функционально она, вероятно, использовалась в качестве украшения костюма.

Типологически рассмотренное изделие может быть отнесено к серии антропоморфных изображений группе 3 варианту «а» по Л. А. Чиндиной $[2$, с. 56], включающему в себя сплошные подвески и бляшки с изображением статичных фигур с непропорционально большой головой; контуры лица, бровей, носа даны одной линией, волосы, сплетенные в косы опущены на плечи. Трехпалые руки упираются в бедра (аналогичное положение зафиксировано на находках с Рёлкинского могильника и Васюганского клада). Одежда заправлена под пояс, оружие на фото не фиксируется. Вместе с тем кислухинскую находку от массы аналогов отличают определенные черты конкретной иконографии: широко открытые глаза и рты, косы, схематично переданная поперечными линиями по вороту, предплечью, запястью и поясу одежда. Фигуры немного отличаются между собой контурами лиц и чертами носов. Возможно, на ногах обозначена обувь, но, к сожалению, более точно судить об этом нельзя в виду некачественного снимка, размещенного в сети. Наибо- 
лее схожими с анализируемым изделием представляются близнечные бляшки, выявленные в кладе на Барсовой горе [3, с. 131].

Широко известны мифоэпические сюжеты о братьях и сестрах-близнецах у народов Ближнего Востока и Центральной Азии (например, Ашвины) [4, с. 174; 5, с. 112]. Для территории Южной Сибири наличие женских близнечных культов в эпоху бронзы у носителей афанасьевской культуры отмечено А. П. Бородовским [6, c. 121]. Косвенным образом в пользу женской интерпретации персонажей на кислухинской пластинке свидетельствует отсутствие у них конических головных уборов, обычно присутствующих на изображениях мужчин [7, с. 67]. Иконография кос рассматриваемых фигур также имеет общие черты с женским изображением из Айдашенской пещеры [8, табл. VI]. Можно предположить, что на пластинке из пос. Кислуха изображены сестры или мать с дочерью. Женские и мужские пары близнецов широко представлены в материалах этнографических комплексов [9, с. 104-105, 125], а сюжет о возможных сибирских репликациях парфянских и римских изображений кос подробно рассмотрен в издании, посвященном Казымскому кладу [10].

О. Н. Корочковой и Н. В. Федоровой, для эпохи раннего железа выделена специальная группа кладов культового литья $[11$, с. 20], к числу которых может относиться и местонахождение у пос. Кислуха, если предположить, что найденные вещи не происходят с территории одного из располагающихся рядом археологических памятников (Малый Гоньбинский кордон, поселения, городища, могильники; Кислянский рыбак-1 поселение [12, с. 44-48; 13 , с. 27-30]).

Представленная находка маркирует проникновение таежного самодийского населения на территорию Верхнего Приобья, отражая косвенным образом процесс освоения им прибрежных близких к борам территорий, елбанов и мысов р. Обь. К сожалению, точная локализация местонахождения остается неизвестной и не обследованной. Неясна и дальнейшая судьба данной находки. Остается надеяться, что обращение автора к органам охраны объектов историко-культурного наследия края не останется без внимания и в ближайшее время находки из пос. Кислуха будут переданы в один из музеев г. Барнаула.

\section{Список литературы}

1. Бородаев В. Б. Новообинцевский клад // Антропоморфные изображения. Первобытное искусство. Новосибирск, 1987. С. 96-114.

2. Чиндина Л. А. История Среднего Приобья в эпоху раннего средневековья. Томск, 1991. $184 \mathrm{c}$.

3. Бельтикова Г.В., Борзунов В.А. Уникальный кулайский клад в Сургутском Приобье // Российская археология. 2017. № 4. C. 124-141.

4. Muфь народов мира: энцикл. Москва, 1991. T.1. $672 \mathrm{c}$.

5. Палагута И.В. Мир искусства древних земледельцев Европы: Культуры балканокарпатского круга в VII-III тыс. до н.э. СанктПетербург, 2011. 336 с.

6. Бородовский А. П. Престижная деревянная утварь с металлическими накладками афанасьевской культуры Саяно-Алтая // Археология, этнография и антропология Евразии. 2013. №4. С. 119-122.

7. Федорова Н. В. Антропоморфные образы Усть-Полуя: технология, иконография, композиция сцен // Уральский исторический вестник. 2014. №2. С. 63-71.

8. Молодин В.И., Бобров В. В., Равнушкин B. Н. Айдашинская пещера. Новосибирск, 1980. $208 \mathrm{c}$.

9. Бауло А. В. Древняя бронза из этнографических комплексов и случайных сборов. Новосибирск, 2011. 260 с.

10. Бауло А. В., Белогай О. И. Казымский клад. Новосибирск, 2020. 248 с.

11. Корочкова О. Н., Федорова Н. В. Клады Урала и Западной Сибири эпохи бронзы - раннего железного века: состав, контексты, интерпретации // Вестник археологии, антропологии и этнографии. 2019. № 3. С. 17-28.

12. Сайберт В. О. Результаты археологической разведки в Тальменском районе Алтайского края в 2016 г. // Сохранение и изучение культурного наследия Алтайского края. 2017. № 23. C. 44-48.

13. Головченко Н.Н., Дьяков Н. Р., Савко И. А. Результаты обследования русловой отмели Федуловской протоки Оби в окрестностях памятника Кислянский рыбак-1 в 2019 г. // Coхранение и изучение культурного наследия Алтайского края. 2020. № 26. С. 27-30. 